\title{
Elevated Serum Leptin Concentrations in Women with Components of Multiple Risk Factor Clustering Syndrome
}

\author{
Miyao Matsubara', Hitoshi Chiba², Shoji Maruoka ${ }^{3}$, and Shinji Katayose ${ }^{3}$ \\ 'Division of Endocrinology \& Metabolism, Internal Medicine, Otaru City General Hospital, Otaru, Japan. \\ ${ }^{2}$ Department of Laboratory Medicine, Hokkaido University School of Medicine, Sapporo, Japan. \\ ${ }^{3}$ Otsuka Assay Institute, Sapporo, Japan.
}

\begin{abstract}
This cross sectional study was undertaken to determine whether serum leptin levels were associated with multiple risk factor (MRF) clustering syndrome. We examined the relationship between serum leptin concentrations and blood pressure (BP), serum lipids levels, calculated insulin resistance (HOMA-ratio) and adiposity among 581 Japanese adult women. The serum leptin was increased in female subjects with systolic $(\geqq 160 \mathrm{mmHg})$ and diastolic $(\geqq 90 \mathrm{mmHg}$ ) hypertension compared with the normotensive females (mean $\pm \mathrm{SE} ; 9.3 \pm 0.5$ vs $7.7 \pm 0.3 ; 10.2 \pm 0.6$ vs $7.1 \pm 0.3 \mathrm{ng} / \mathrm{ml}$, both $p<0.001$ ). Serum leptin was elevated in those with hyper-cholesterolemia ( $; \geqq 220 \mathrm{mg} / \mathrm{dl}$ ) and triglyceridemia (TG ; $\geqq 150 \mathrm{mg} / \mathrm{dl}$ ) compared with the normolipidemia $(9.4 \pm 0.4$ vs $7.8 \pm 0.3 ; 11.7 \pm 0.6$ vs $7.5 \pm 0.2 \mathrm{ng} / \mathrm{ml}$, both $p<0.001$ ). Serum leptin was also elevated in those with adiposity (BMI $\geqq 26.4 \mathrm{~kg} / \mathrm{m}^{2}$ ) and insulin resistance (HOMA-ratio $\geqq 2.5)$ compared with the normal females (14.8 \pm 0.7 vs $5.2 \pm 0.2 ; 11.3 \pm 1.1$ vs $7.1 \pm 0.4 \mathrm{ng} / \mathrm{ml}$, both $p<0.001$ ). Even after adjusting for BMl or percent body fat mass (BFM), leptin levels remained to be elevated significantly in all these diseases. There was a positive correlation between serum leptin and systolic, diastolic BP, TC, TG, BMI, BFM, IRI and HOMA-ratio $(r=0.12, p=0.005 ; r=0.24, p<0.0001 ; r=0.19$, $p<0.0001 ; r=0.35, p<0.0001 ; r=0.72, p<0.0001 ; r=0.73, p<0.0001 ; r=0.47, p<$ $0.0001 ; r=0.44, p<0.0001)$, and a negative correlation with HDL-C levels $(r=-0.20, p<$ 0.0001). These correlations were also observed in leptin levels after adjusting for the BMI or BFM. Multiple regression analysis showed that BFM, HOMA-ratio and TG were significant determinants of leptin concentration before $(t=12.6, p<0.0001 ; t=3.33, p=0.001 ; t=$ 3.22, $p=0.001$ ) and after adjusting for BMI or BFM.These results suggest that because serum leptin levels were elevated in components of MRF clustering syndrome, leptin may have a pathophysiological role in MRF clustering syndrome. $J$ Atheroscler Thromb,
\end{abstract} $2000 ; 7$ : $231-237$.

Key words : Leptin, Multiple risk factor clustering syndrome, Insulin resistance, Adiposity

\section{Introduction}

Leptin, the obese $(o b)$ gene product, is a $16-\mathrm{kDa}$ peptide hormone secreted by adipocytes $(1,2)$. It is thought to be a homeostatic signal that contributes to body weight

Address for correspondence: Miyao Matsubara MD, Division of Endocrinology \& Metabolism, Internal Medicine, Otaru City General Hospital, Wakamatsu 1-2-1, Otaru $047-$ 0017, Japan.

Received September 20, 2000

Accepted for publication November 30, 2000. regulation through modulating feeding behavior and/or energy expenditure (2-7). This feedback loop appears to be disturbed in obesity (5-7). Obesity is often accompanied by disturbances in blood pressure (BP) or lipid metabolism related to insulin resistance (8-11). Recent studies suggest a complex interrelationship between leptin and insulin resistance (12-16).

Hypertension, hyperlipidemia and low-high density lipoprotein (HDL) cholesterolemia, adiposity and insulin resistance are major risk factors for atherosclerotic diseases, such as cardiovascular and cerebrovascular diseases, 
and recently the coexistence has been variously called multiple risk factor (MRF) clustering syndrome, syndrome $X$ or the deadly quartet (8-11). Whether high levels of leptin are associated with hypertension (HT), dyslipidemia and insulin resistance per se, independent of concomitant adiposity, is not completely understood. If an independent association was found, this would support the hypothesis that leptin may regulate $\mathrm{BP}$, serum lipids and insulin resistance, and thus play an important pathophysiologic role in MRF clustering syndrome.

This study was undertaken to examine the association between BP, serum lipids, calculated insulin resistance, and serum leptin concentrations among a random sample of Japanese adult women in a cross sectional manner.

\section{Subjects and Methods}

\section{Subjects}

Five hundred and eighty one Japanese female subjects residing in Hokkaido, Japan, excluding those with diabetes mellitus or untreated endocrine diseases, were included in this study. Participants were recruited and examined between January 1998 and February 2000. Approximately $24,21 \%$ of females had systolic or diastolic HT (Table 1), 86 (15\%) were receiving calcium antagonists and/or angiotensin converting enzyme inhibitors, and 71 hyperlipidemic females (type lla or $\mathrm{Ilb})(13 \%)$ were using HMG-CoA reductase inhibitors. All subjects underwent extensive examinations for cardiovascular risk factor testing. All anthropometric measures were made with the participant wearing light clothes and no shoes. Body mass index (BMI) was calculated as weight in kilograms divided by the square of the height in meters. Body fat mass (BFM) was determined by bioelectrical impedance analysis ; this was the mean value determined using both a Tanita Body Fat Analyzer (TBF-541, TANITA, Tokyo) and an Omron Body Fat Analyzer (HBF-301,OMRON, Tokyo) (17).

Blood samples after overnight fasting were collected for determination of blood glucose (FBG), immunoreactive insulin (IRI), lipids [total cholesterol (TC), triglyceride (TG) and $\mathrm{HDL}$ cholesterol (HDL-C)] and leptin, and the serum was frozen at $-80^{\circ} \mathrm{C}$ until analysis.

\section{Biochemical analyses}

The FBG was measured by the glucose oxidase method, and IRI was determined by a specific EIA with reagents from Dynabot Co. Ltd., Japan. Insulin resistance was calculated by the homeostasis model assessment (HOMA) method, using FBG and insulin concentration $(15,18)$. Assuming that normal-weight normal subjects $<35$ years of age have an insulin resistance of 1 , the value for insulin resistance can be assessed by the formula: FBG $(\mathrm{mg} / \mathrm{dl}) \times \mathrm{IRI}(\mu \mathrm{U} / \mathrm{ml}) / 405$. Results of the HOMA-ratio $(R)$ correlated well with measurements obtained by means of the euglycemic clamp technique, as was shown in the HOMA method validation study (18).

Serum leptin concentration was measured with a RIA (Linco Research Inc., St. Charles, MO), which uses a polyclonal antibody raised in rabbits against recombinant human leptin $(17,19)$. The assay had a sensitivity of 0.5 $\mathrm{ng} / \mathrm{ml}$.

\section{Statistical analyses}

Serum leptin concentrations in all female subjects were compared among the following groups. Systolic and diastolic BP were divided into 3 groups, respectively: $\sim<140 \mathrm{mmHg}$ was normal systolic BP $(n=251), 140 \leqq$ $\sim<160$ slightly systolic HT (184), $160 \leqq \sim$ systolic HT (136), and $\sim<80 \mathrm{mmHg}$ was normal diastolic BP $(n=230), 80 \leqq$ $\sim<90$ border range (219), $90 \leqq \sim$ diastolic HT (122). Serum TC and TG levels were divided into two groups,

Table 1. The clinical and biochemical characteristics in studied female subjects.

\begin{tabular}{|c|c|c|c|c|}
\hline & & mean $\pm S E$ & (range) & prevalences (\%) \\
\hline$n$ & & 581 & & \\
\hline age & (years) & $51.9 \pm 0.7$ & $(18 \sim 86)$ & \\
\hline serum leptin & (ng/ml) & $8.4 \pm 0.2$ & $(1.2 \sim 43.9)$ & \\
\hline systolic blood pressure & $(\mathrm{mmHg})$ & $140.9 \pm 0.9$ & $(88 \sim 210)$ & $23.8(\geqq 160)$ \\
\hline diastolic blood pressure & $(\mathrm{mmHg})$ & $80.1 \pm 0.5$ & $(50 \sim 130)$ & $21.4(\geqq 90)$ \\
\hline \multicolumn{5}{|c|}{ Variables related to body adiposity } \\
\hline $\mathrm{BMI}$ & $\left(\mathrm{kg} / \mathrm{m}^{2}\right)$ & $23.1 \pm 0.2$ & $(12.7 \sim 41.2)$ & $17.2(\geqq 26.4)$ \\
\hline body fat mass & $(\mathrm{kg})$ & $16.8 \pm 0.3$ & $(1.9 \sim 46.7)$ & \\
\hline body fat mass & $(\%)$ & $30.1 \pm 0.3$ & $(6.7 \sim 56.5)$ & \\
\hline \multicolumn{5}{|c|}{ Variables related to serum lipids } \\
\hline serum total cholesterol (C) & $(\mathrm{mg} / \mathrm{dl})$ & $205.4 \pm 1.5$ & $(108 \sim 329)$ & $34.6(\geqq 220)$ \\
\hline serum triglyceride & (mg/dl) & $106.4 \pm 2.7$ & $(18 \sim 591)$ & $18.5(\geqq 150)$ \\
\hline serum $\mathrm{HDL} \cdot \mathrm{C}$ & $(\mathrm{mg} / \mathrm{dl})$ & $63.9 \pm 0.7$ & $(25 \sim 138)$ & $8.1(<45)$ \\
\hline \multicolumn{5}{|c|}{ Variables related to insulin resistance } \\
\hline FBG & $(\mathrm{mg} / \mathrm{dl})$ & $93.7 \pm 1.0$ & $(64 \sim 125)$ & \\
\hline fasting IRI & $(\mu \mathrm{U} / \mathrm{ml})$ & $7.1 \pm 0.3$ & $(1.1 \sim 35.6)$ & \\
\hline HOMA-ratio & & $1.7 \pm 0.1$ & $(0.2 \sim 7.7)$ & $16.6(\geqq 2.5)$ \\
\hline
\end{tabular}


normal range and hyperlipidemia $(T C \geqq 220, T G \geqq 150 \mathrm{mg} /$ dl) by the Japan Atherosclerosis Society criteria. BMI was divided into 3 groups : $\sim<22.0 \mathrm{~kg} / \mathrm{m}^{2}$ was thin or standard level ( $n=244), 22.0 \leqq \sim<26.4$ overweight (224), and $26.4 \leqq \sim$ adiposity level (97). The diagnosis of insulin resistance was based on a HOMA-ratio of 2.5 or higher, which was calculated in the formula: $11.0 \times 93.7 \div 405=$ 2.5. The $11.0 \mu \mathrm{U} / \mathrm{ml}$ of fasting IRI was an arbitrary value obtained from the mean \pm SD $(7.1 \pm 3.9)$, and $93.7 \mathrm{mg} / \mathrm{dl}$ was the mean FBG value of these female subjects. Since preliminary analyses indicated that the distributions of serum leptin, TG, IRI and HOMA-R were skewed, log transformation was used, which yielded more normally distributed data. Comparisons among groups were performed with one-way ANOVA using Scheffe's test for multiple comparisons before and after adjusting for BMI or BFM. Linear regression was performed to determine which factor among age, BP, BMI, BFM, TC, TG, HDL-C, FBG, IRI and HOMA-R correlated with log-transformed leptin before and after adjusting for BMI or BFM. Multiple linear regression analysis was performed with logtransformed leptin before and after adjusting for BMI or $B F M$ as the dependent variable and BFM, log-transformed HOMA-R, TG and diastolic BP as independent variables. Before fitting the model, potential effects of collinearity were examined using correlation matrices. $p<0.05$ was considered to be statistically significant.

\section{Results}

The characteristics of determinants related to BP, body adiposity, serum lipids, insulin resistance and each other of the study population are shown in Table 1 . The fasting serum leptin concentration ranged from 1.2 to $43.9 \mathrm{ng} / \mathrm{ml}$, with a geometric mean of 8.4 .

As shown in Fig. 1A, the mean serum leptin concentration (mean \pm SE) was significantly elevated in systolic $(\geqq 160 \mathrm{mmHg}$ ) and diastolic hypertensive females ( $\geqq 90$ $\mathrm{mmHg}$ ) compared with the normotensive subjects $(9.3 \pm$ 0.5 vs $7.7 \pm 0.3 ; 10.2 \pm 0.6$ vs $7.1 \pm 0.3 \mathrm{ng} / \mathrm{ml}$, both $p<$ 0.001). Serum leptin in hypercholesterolemia ( $\geqq 220 \mathrm{mg} /$ dl) was significantly increased compared with that in normocholesterolemia $(9.4 \pm 0.4$ vs $7.8 \pm 0.3 \mathrm{ng} / \mathrm{ml}, p<$ 0.001). Serum leptin levels in females with elevated $T G$ levels ( $\geqq 150 \mathrm{mg} / \mathrm{dl}$ ) were higher than those in normal TG subjects $(11.7 \pm 0.6$ vs $7.5 \pm 0.2 \mathrm{ng} / \mathrm{ml}, p<0.001)$. In obesity $\left(B M I \geqq 26.4 \mathrm{~kg} / \mathrm{m}^{2}\right)$ serum leptin levels were significantly higher than those in normal subjects $(14.8 \pm 0.7$ vs $5.2 \pm 0.2 \mathrm{ng} / \mathrm{ml}, p<0.001)$. Serum leptin in elevated HOMA-R ( $\geqq 2.5)$ was also significantly higher than that in normal females $(11.3 \pm 1.1 \mathrm{vs} 7.1 \pm 0.4 \mathrm{ng} / \mathrm{ml}, p<0.001)$.

As body adiposity was the strongest determinant of leptin in women $(7,12,13,17)$, we compared the leptin levels after adjusting for the BMI or BFM, with a significant increase of log-transformed leptin/BMI and leptin/ BFM in females with $\mathrm{HT}$, hyper-TC, -TG, obesity and insulin resistance (Fig. 1B).

The association between log-transformed leptin before and after adjusting for BMI or BFM and selected variables is presented in Table 2. Measures of adiposity were strongly correlated with leptin levels $(r=0.72 \sim 0.73$, both $p<0.0001$ ) (Fig. 2). There was a significant positive rela-

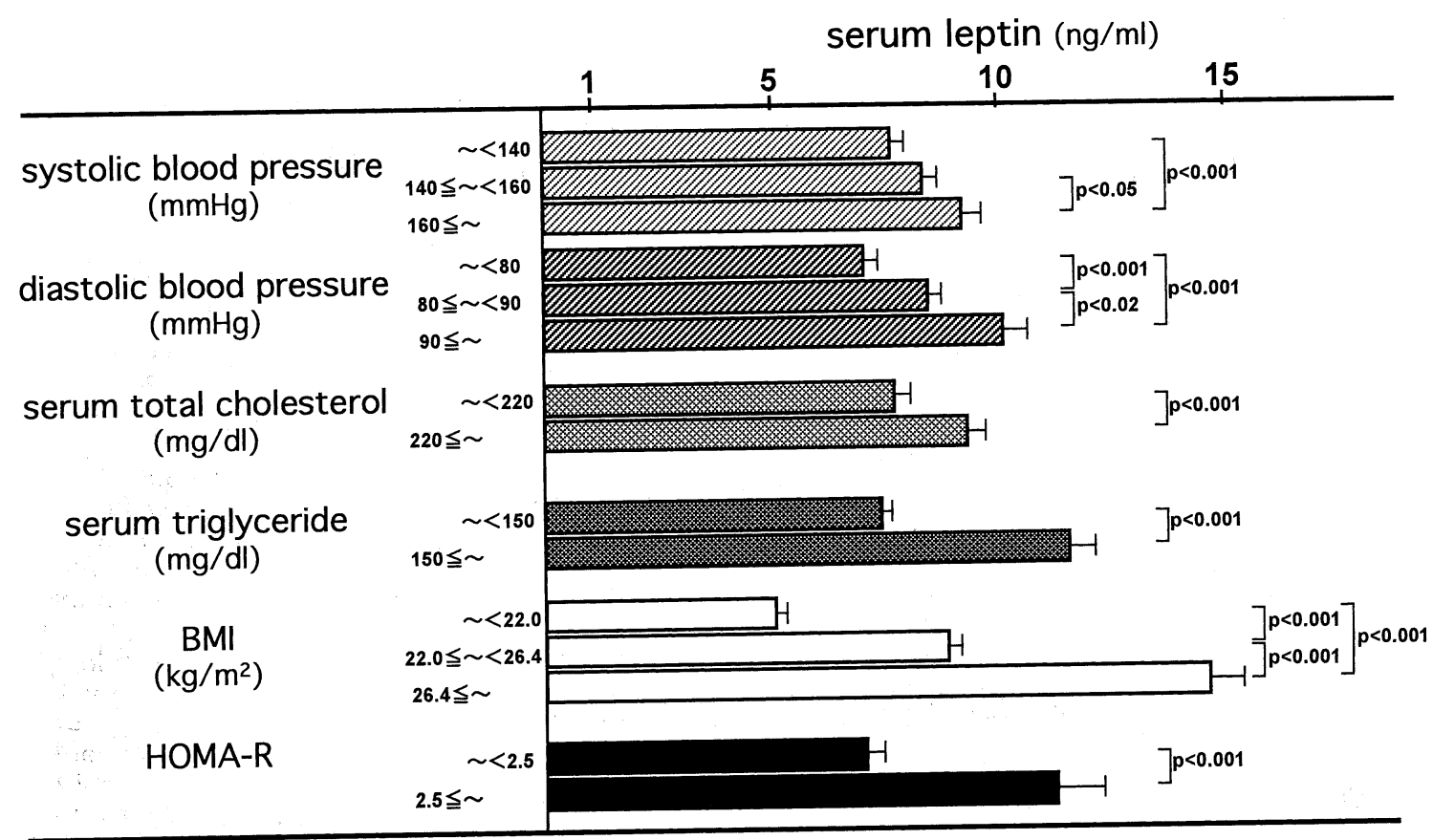

Fig. 1A. Serum leptin levels in hypertension, hyperlipidemia, adiposity and insulin resistance (mean \pm $\mathrm{SE})$. 


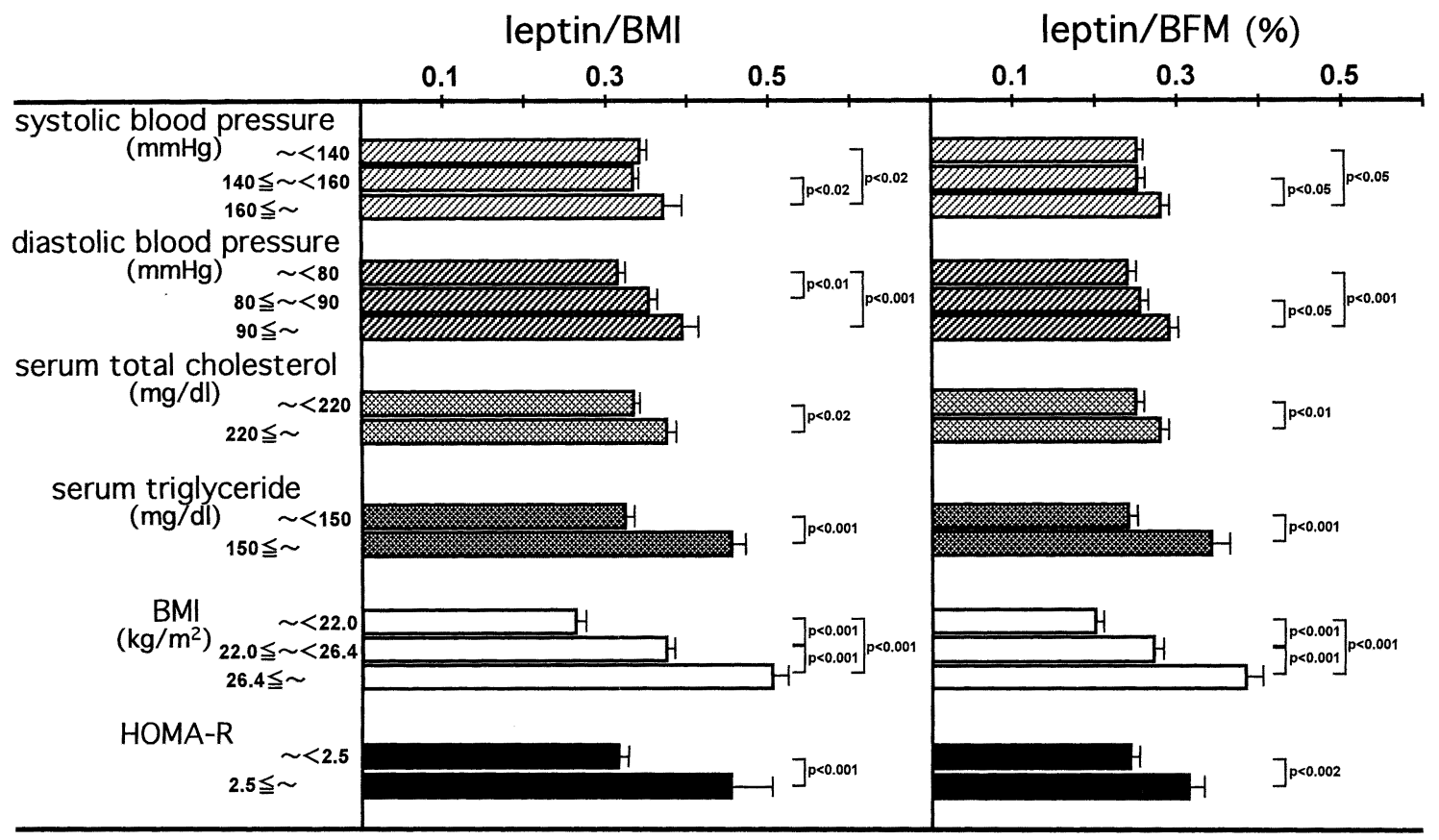

Fig. 1B. Leptin/BMI and leptin/BFM(\%) values in hypertension, hyperlipidemia, adiposity and insulin resistance (mean $\pm \mathrm{SE})$.

tionship between log-transformed leptin and systolic, diastolic BP, TC, log-transformed TG, IRI, or HOMA-R ( $r=$ $0.12, p=0.005 ; r=0.24, p<0.0001 ; r=0.19, p<0.0001$; $r=0.35, \quad p<0.0001 ; r=0.47, \quad p<0.0001 ; r=0.44, \quad p<$ 0.0001) (Fig. 2). Moreover, a weak inverse correlation between leptin and HDL-C levels was found $(r=-0.20$, $p<0.0001$ ). These correlations were also observed in leptin levels after adjusting for the BMI or BFM (Table 2). Multiple regression analysis showed that BFM, HOMA-R and TG were significant determinants of the fasting leptin concentration before and after adjusting for BMI or BFM (Table 3).

\section{Discussion}

Various studies have shown that body adiposity and gender are the major determinants of leptin, and BMI has been said to be the strongest determinant of leptin in women $(7,12-15,17)$, but we found no association between serum leptin concentration and aging $(r=0.019$, $p=0.641)$. We attempted to study the association of leptin with BP, lipids metabolism and insulin resistance, independent of body adiposity in female subjects. In the present study, the serum leptin concentrations before and after adjusting for BMI or BFM were elevated in women with MRF clustering syndrome-composing diseases such as $\mathrm{HT}$, hyperlipidemia, adiposity and insulin resistance, and correlated significantly with these related parameters. Furthermore, from the multiple regression analysis, BFM, HOMA-R and TG levels were related to leptin levels before and after adjusting for BMI or BFM. Our results suggest that leptin may be involved in regulating BP, serum lipids metabolism and insulin resistance independent of the concomitant adiposity.

Shek et al. directly tested in rats by chronic administering leptin and measuring $\mathrm{BP}(20)$. Others $(14,15,21)$ have indicated that leptin may modify the increasing BP in humans, but Sheu et al. reported an unchanged serum leptin concentrations in females with HT(22). Leptin increases norepinephrine turnover and sympathetic nerve activity in rodents and humans $(21,23,24)$. We also found that BP was positively associated with leptin in women.

Several studies have found an association of TG with leptin in men after adjustment for body fat assessed by skinfold measurements or after adjustment for BMI and insulin sensitivity $(14,15,25)$. It is possible that serum TG levels are affected by leptin, e.g., by indirect mechanisms involved in insulin resistance.

The relationship between insulin and leptin, which was also found in our study, is in concordance with reported findings in humans showing an induction of $o b$ gene expression and an increase in leptin concentrations by insulin infusion, possibly due to the trophic effect of insulin on adipocytes $(15,26)$. In in vivo studies, however, leptin has been reported to improve insulin sensitivity and the glucose metabolism in normal and obese rodents, acting mainly through the hypothalamus (27). Moreover leptin has been reported to have antidiabetic effects in insulin-deficient diabetes rats and lipoatrophic 

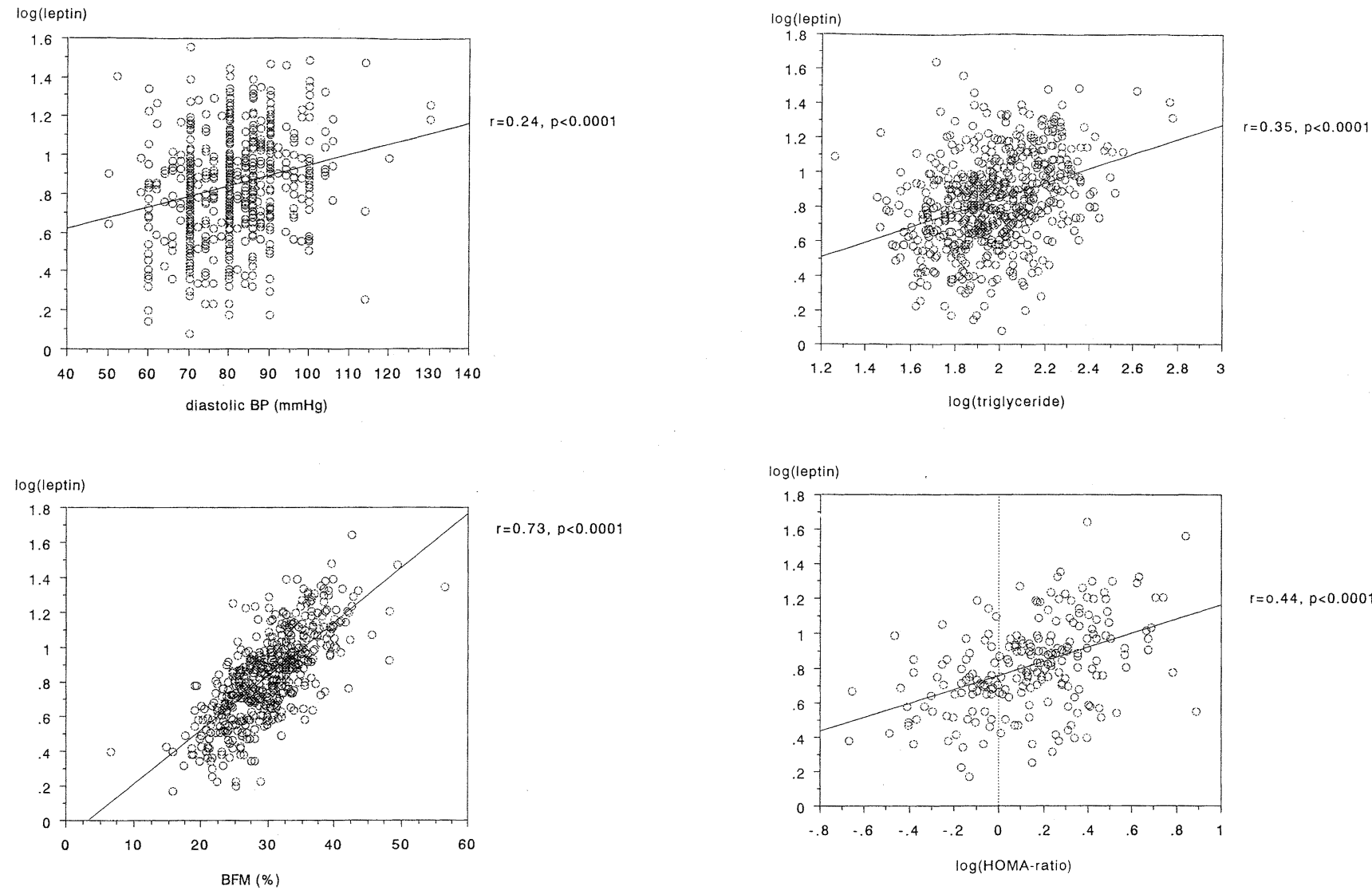

Fig. 2. The correlations between the leptin and diastolic blood pressure, body fat mass(BFM), serum triglyceride, or homeostasis model assessment (HOMA)-ratio.

Table 2. The correlation between log-transformed leptin levels before and after adjusting for BMI or $\mathrm{BFM}$ and variables associated with multiple risk factor clustering syndrome.

\begin{tabular}{|c|c|c|c|c|c|c|}
\hline & \multicolumn{2}{|c|}{ leptin } & \multicolumn{2}{|c|}{ leptin/BMI } & \multicolumn{2}{|c|}{ leptin/BFM (\%) } \\
\hline & $r$ & $p$ & $r$ & $p$ & $r$ & $p$ \\
\hline age & 0.019 & 0.641 & 0.032 & 0.444 & 0.046 & 0.311 \\
\hline systolic blood pressure & 0.117 & 0.005 & 0.059 & 0.163 & 0.060 & 0.187 \\
\hline diastolic blood pressure & 0.235 & $<0.0001$ & 0.162 & 0.0001 & 0.149 & 0.001 \\
\hline $\mathrm{BMI}$ & 0.717 & $<0.0001$ & 0.555 & $<0.0001$ & 0.529 & $<0.0001$ \\
\hline BFM (\%) & 0.727 & $<0.0001$ & 0.595 & $<0.0001$ & 0.480 & $<0.0001$ \\
\hline total cholesterol (C) & 0.191 & $<0.0001$ & 0.142 & 0.0008 & 0.127 & 0.005 \\
\hline $\log$ (triglyceride) & 0.351 & $<0.0001$ & 0.306 & $<0.0001$ & 0.292 & $<0.0001$ \\
\hline $\mathrm{HDL} \cdot \mathrm{C}$ & -0.196 & $<0.0001$ & -0.172 & $<0.0001$ & -0.159 & 0.0005 \\
\hline FBG & 0.084 & 0.106 & 0.052 & 0.319 & 0.043 & 0.425 \\
\hline $\log (\mathrm{IRI})$ & 0.465 & $<0.0001$ & 0.475 & $<0.0001$ & 0.425 & $<0.0001$ \\
\hline $\log ($ HOMA-R) & 0.439 & $<0.0001$ & 0.440 & $<0.0001$ & 0.388 & $<0.0001$ \\
\hline
\end{tabular}

diabetes mice $(28,29)$.

The serum leptin concentration correlated positively and was primarily determined by fat mass in confirming other studies $(2-7,12-17)$. The increased leptin levels with adiposity are due to augmented ob gene expression and increased leptin production, involving enlargement of adipocytes. Masuzaki et al. (30) found subcutaneous fat to express more leptin mRNA than intraabdominal fat.
Thus visceral android adipose tissue may produce less leptin than peripheral gynecoid fat, accounting for the differences between males and females. Further studies are needed to confirm our findings in this study also in males.

This study was undertaken to test the hypothesis that fasting leptin was associated with MRF syndrome, independent of adiposity. Our results provide evidence in 
Table 3. The multiple regression analysis of selected variables on log-transformed leptin levels before and after adjusting for BMI or BFM [independent variables included body fat mass (BFM) (\%), log-transformed HOMA-ratio, triglyceride (TG), and diastolic blood pressure (d-BP)].

\begin{tabular}{|c|c|c|c|c|c|c|c|c|c|}
\hline & \multicolumn{3}{|c|}{ leptin } & \multicolumn{3}{|c|}{ leptin/BMI } & \multicolumn{3}{|c|}{ leptin/BFM(\%) } \\
\hline & $\begin{array}{l}\text { standardized } \\
\text { regression } \\
\text { coefficient }\end{array}$ & $t$ & $p$ & $\begin{array}{l}\text { standardized } \\
\text { regression } \\
\text { coefficient }\end{array}$ & $t$ & $p$ & $\begin{array}{c}\text { standardized } \\
\text { regression } \\
\text { coefficient }\end{array}$ & $t$ & $p$ \\
\hline BFM (\%) & 0.675 & 12.63 & $<0.0001$ & 0.529 & 8.57 & $<0.0001$ & 0.415 & 6.13 & $<0.0001$ \\
\hline $\log (\mathrm{HOMA}-\mathrm{R})$ & 0.165 & 3.33 & 0.001 & 0.225 & 3.89 & 0.0001 & 0.218 & 3.45 & 0.0007 \\
\hline $\log (T G)$ & 0.116 & 3.22 & 0.001 & 0.122 & 3.04 & 0.0025 & 0.148 & 3.38 & 0.0008 \\
\hline$d \cdot B P$ & -0.03 & -0.60 & 0.549 & -0.069 & -1.21 & 0.226 & -0.041 & -0.65 & 0.515 \\
\hline
\end{tabular}

favour of this hypothesis and further suggest that leptin may affect the risk of arteriosclerosis, separate from the risk due to adiposity.

In summary, we have found that serum leptin concentrations before and after adjusting for BMI or BFM are associated with components of MRF clustering syndrome, such as HT, dyslipidemia, adiposity and insulin resistance in women. Furthermore, our data are consistent with the hypothesis that serum leptin may have an independent effect on BP, lipids metabolism and insulin resistance that is not entirely explained by adiposity. Further work is needed to explore the mechanisms of leptin resistance and implications of leptin elevation in MRF clustering syndrome.

\section{References}

(1) Zhang $Y$, Proenca R, Maffei M, Barone M, Leopold L, and Friedman JM: Positional cloning of the mouse obese gene and its human homologue. Nature, 372 : 425-432, 1994

(2) Campfield LA, Smith FJ, Guisez Y, Devos R, and Burn P: Recombinant mouse ob protein: Evidence for a peripheral signal linking adiposity and central neural networks. Science, 269: 546-549, 1995

(3) Halaas JL, Gajiwala KS, Maffei M, Cohen SL, Chait BT, Rabiniwitz D, Lallone RL, Burley SK, and Friedman JM: Weight-reducing effects of the plasma proteins encoded by the obese gene. Science, 269: 543-546, 1995

(4) Frederich RC, Hamann A, Anderson S, Löllmann B Lowell BB, and Flier JS : Leptin levels reflect body lipid content in mice: Evidence for diet-induced resistance to leptin action. Nat Med, 1: 1311-1314, 1995

(5) Lönnqvist F, Arner $P$, Nordfors L, and Schalling M: Over expression of the obese(ob) gene in adipose tissue of human obese subjects. Nat Med, 1: 950-953, 1995

(6) Maffei M, Halaas J, Ravussin E, Pratley RE, Lee GH, Zhang Y, Fei H, Kim S, Lallone R, Ranganathan S, Kern $\mathrm{PA}$, and Friedman JM: Leptin levels in human and rodents: Measurement of plasma leptin and ob RNA in obese and weight-reduced subjects. Nat Med, 1: 11551161, 1995

(7) Considine RV, Sinha MK, Heiman ML, Kriauciunas A, Stephens TW, Nyce MR, Ohannesian JP, Marco CC, Mckee LJ, Bauer TL, and Caro JF: Serum immunoreactive-leptin concentrations in normal-weight and obese humans. N Engl J Med, 334: 292-29, 1996
(8) Reaven GM : Role of insulin resistance in human disease. Diabetes, 37 : 1595-1607, 1988

(9) Kaplan NM : The deadly quartet: Upper-body obesity, glucose intolerance, hypertriglyceridemia, and hypertension. Arch Intern Med, 149: 1514-1520, 1989

(10) DeFronzo RA and Ferrannini E: Insulin resistance: A multifaceted syndrome responsible for NIDDM, obesity, hypertension, dyslipidemia, and atherosclerotic cardiovascular disease. Diabetes Care, 14 : 173-194, 1991

(11) Nakamura T, Tokunaga K, Shimomura I, Nishida $M$, Yoshida S, Kotani K, Islam AH, Keno Y, Kobatake T, Nagai Y, Fujioka S, Tarui S, and Matsuzawa Y : Contribution of visceral fat accumulation to the development of coronary artery disease in non-obese men. Atherosclerosis, 107 : 239-246, 1994

(12) Mantzoros CS : The role of leptin in human obesity and disease: A review of current evidence. Ann Intern Med, 130: 671-68, 1999

(13) Tritos N and Mantzoros CS: Leptin: Its role in obesity and beyond. Diabetologia, 40 : 1371-1379, 1997

(14) Staten $M$, de Courten M, Zimmet P, Hodge A, Collins V, Nicolson $M$, Dowse $G$, and Alberti KG: Hyperleptinaemia: The missing link in the metabolic syndrome? Diabet Med, 14 : 200-208, 1997

(15) Ruige JB, Mooy J, Dekker JM, Kostense PJ, Blum WF, Bouter LM, Stehouwer CDA, Heine RJ, and Nijpels G: Leptin and variables of body adiposity, energy balance, and insulin resistance in a population-based study. Diabetes care, 22: 1097-1104, 1999

(16) Donahue RP, DeCourten M, Prineas RJ, Collier G, Donahue RDC, Goldberg RB, Zimmet P, Skyler JS, Bean JA, and Schneiderman $\mathrm{N}$ : Is fasting leptin associated with insulin resistance among nondiabetic individuals? Diabetes Care, 22 : 1092-1096, 1999

(17) Matsubara M, Yoshizawa T, Morioka T, and Katayose S : Serum leptin and lipids in patients with thyroid dysfunction. J Atheroscler Thromb, 7: 50-54, 2000

(18) Matthews DR, Hosker JP, Rudenski AS, Naylor BA, Treacher DF, and Turner RC: Homeostasis model assessment: Insulin resistance and beta-cell function from fasting plasma glucose and insulin concentrations in man. Diabetologia, 28: 412-419, 1985

(19) Ma Z, Gingerich RL, Santiago JV, Klein S, Smith $\mathrm{CH}$, and Landt $\mathrm{M}$ : Radioimmunoassay of leptin in human plasma. Clin Chem, 42 : 942-946, 1996

(20) Shek EW, Brands MW, and Hall JE : Chronic leptin infusion increases arterial pressure. Hypertension, 31: 409-414, 1998

(21) Snitker S, Pratley RE, Nicolson M, Tataranni PA, and Ravussin E: Relationship between muscle sympathetic 
nerve activity and plasma leptin concentration. Obes Res, 5 : 338-340, 1997

(22) Sheu WHH, Lee WJ, and Chen YT: High plasma leptin concentrations in hypertensive men but not in hypertensive women. J Hypertens, 17 : 1289-1295, 1999

(23) Haynes WG, Sivitz WI, Morgan DA, Walsh SA, and Mark $\mathrm{AL}$ : Sympathetic and cardiorenal actions of leptin. Hypertension, 30 : 619-623, 1997

(24) Dunbar JC, $\mathrm{Hu} \mathrm{Y}$, and $\mathrm{Lu} \mathrm{H}$ : Intracerebroventricular leptin increases lumbar and renal sympathetic nerve activity and blood pressure in normal rats. Diabetes, 46: 2040-2043, 1997

(25) Tuominen JA, Ebeling P, Laquier FW, Heiman ML, Stephens $T$, and Koivisto VA: Serum leptin concentration and fuel homeostasis in healthy man. Eur J Clin Invest, 27 : 206-211, 1997

(26) Kolaczynski JW, Nyce MR, Considine RV, Boden G, Nolan JJ, Henry R, Mudaliar SR, Olefsky J, and Caro JF : Acute and chronic effects of insulin on leptin production in humans: Studies in vivo and in vitro. Diabetes, 45 :
699-701, 1996

(27) Kamohara S, Burcelin R, Halaas JL, Friedman JM, and Charron MJ: Acute stimulation of glucose metabolism in mice by leptin treatment. Nature, 389: 374-377, 1997

(28) Ogawa Y, Masuzaki H, Hosoda K, Aizawa-Abe M, Suga J, Suda M, Ebihara K, Iwai $H$, Matsuoka N, Satoh N, Odaka H, Kasuga H, Fujisawa Y, Inoue G, Nishimura H, Yoshimasa $Y$, and Nakao $\mathrm{K}$ : Increased glucose metabolism and insulin sensitivity in transgenic skinny mice overexpressing leptin. Diabetes, 48: 1822-1829, 1999

(29) Chinookoswong N, Wang JL, and Shi ZQ: Leptin restores euglycemia and normalizes glucose turnover in insulin-deficient diabetes in the rat. Diabetes, 48: 1487-1492, 1999

(30) Masuzaki H, Ogawa Y, Isse N, Satoh N, Okazaki T, Shigemoto M, Mori K, Tamura N, Hosoda K, Yoshimasa $\mathrm{Y}$, Jingami $\mathrm{H}$, Kawada $\mathrm{T}$, and Nakao K: Human obese gene expression: Adipocyte-specific expression and regional differences in the adipose tissue. Diabetes, $44: 855-858,1995$ 